\title{
MEASUREMENTS OF CURRENT-VOLTAGE CHARACTERISTICS OF HIGH-SPEED SiC AND GaN POWER DEVICES IN NANOSECOND TIME SCALE*
}

\author{
L. Ardaravičius ${ }^{\text {a }}$, M.J. Kelly ${ }^{\mathrm{b}}$, M. Kappers ${ }^{\mathrm{c}}$, O. Kiprijanovič ${ }^{\mathrm{a}}$, and S. Whelan ${ }^{\mathrm{b}}$ \\ a Semiconductor Physics Institute, A. Goštauto 11, LT-01108 Vilnius, Lithuania \\ E-mail: linas@pfi.lt \\ ${ }^{\mathrm{b}}$ Centre for Advanced Photonics and Electronics, Department of Engineering, University of Cambridge, 9 JJ Thomson \\ Avenue, Cambridge CB1 1EG, United Kingdom \\ ${ }^{\mathrm{c}}$ Department of Materials Science and Metallurgy, University of Cambridge, Cambridge CB2 3QZ, United Kingdom
}

Received 26 September 2008; revised 2 February 2009; accepted 19 March 2009

\begin{abstract}
Wide gap semiconductors such as $\mathrm{GaN}$ and $\mathrm{SiC}$ have extremely large values of breakdown fields. Measurements of currentvoltage characteristics of the wide gap semiconductor devices using power electrical pulses can induce damage of the devices due to Joule heating. In our experiments the $4 \mathrm{H}-\mathrm{SiC}$ sample and the $\mathrm{GaN}$ Gunn diode were placed in series to the transmission line, and a gauge resistor was used for the determination of incident pulse amplitude, in order to perform measurements using nanosecond pulses and, by this, to eliminate Joule heating. It is argued that the devices operating at high electric field (over $50 \mathrm{kV} / \mathrm{cm}$ ) can be damaged by electrical pulses of nanosecond duration due to overheating which begins at submicron inhomogeneities during the pulse rise time.
\end{abstract}

Keywords: GaN, 4H-SiC, pulsed VACH measurement, high electric field effects

PACS: 65.40.-b, 71.55.Eq, 72.20.Ht, 73.50.Fq

\section{Introduction}

The method of measuring the current-voltage $(I-V)$ characteristics using rectangular electric pulses of nanosecond time duration was proposed in 1970 [1]. The sample was placed at the end of transmission line and results were obtained by comparing incident and reflected pulse amplitudes. Using nanosecond pulses allows the elimination of relatively slow processes, mainly Joule heating. Some practical applications of this method are described in Ref. [2].

Recent progress in wide gap semiconductor $(\mathrm{SiC}$, $\mathrm{GaN})$ technologies leads to creation of diodes with blocking voltages as high as $10 \mathrm{kV}$, metal-semiconductor field effect transistors (MESFETs), and high electron mobility transistors (HEMTs) with two-dimensional electron gas channel. Carrier concentration in the channel is above $10^{13} \mathrm{~cm}^{-2}$ and room temperature mobility is above $1000 \mathrm{~cm}^{2} /(\mathrm{V} \mathrm{s})$ [3]. The devices have to be of micron size and to have structures of nanome-

\footnotetext{
* Results presented at the international conference Radiation Interaction with Material and Its Use in Technologies 2008, 24-27 September 2008, Kaunas, Lithuania
}

tre size in order to operate at high frequencies (10$100 \mathrm{GHz}$ ). During the $I-V$ measurements of the devices at high electric fields undesirable processes appear, such as avalanche breakdown, hot electron trapping, and others, having times constants of order of nanoseconds $[4,5]$. This leads to changing nanosecond pulse plateau with time, and therefore the dynamics of the device damage, induced by the power nanosecond pulse, becomes visible. Other investigators also indicate on possible weakening of the materials' parameters after the real devices have been made [6]. In order to obtain the $I-V$ results of GaN diode at over $150 \mathrm{~V}$ the authors of [7] have used a conical shape of the diode and $n^{+}$-GaN substrate of $300 \mu \mathrm{m}$ thickness.

In this work we introduce experimental results obtained during the $I-V$ measurements of gateless $4 \mathrm{H}-\mathrm{SiC}$ channel layers for MESFETs and GaN vertical diode structure, fabricated to demonstrate negative differential resistance at high electric fields. $I-V$ measurements were performed at modified nanosecond pulsed system. The reasons are analysed why the device degradation occurs at high electric fields. 


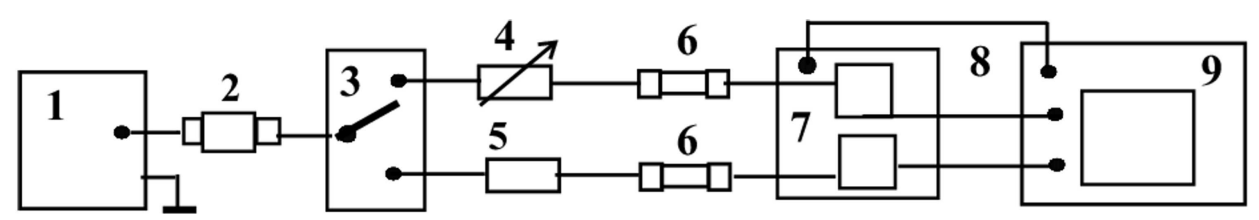

Fig. 1. Schematic diagram of the experimental set-up. 1 is a nanosecond pulse generator, 2 power attenuator, 3 wide band switch, 4 gauge resistor, 5 device under test, 6 attenuators, 7 delay line, 8 synchronization, 9 sampling oscilloscope.

\section{Experimental technique}

A schematic diagram of the experimental set-up is shown in Fig. 1. It consists of a nanosecond pulse generator in which the pulse duration depends on the charged line length (1), power attenuator (2), high voltage wideband switch (3), variable super high frequency gauge resistor (4), device under test (DUT) (5), thin film attenuator $(6)$, delay line (70 ns) having transient response $100 \mathrm{ps}(7)$, synchronization (8), and a 2-channel sampling oscilloscope (9).

In our $I-V$ measurements the DUT 5 is placed in a break in the transmission line and a gauge resistor 4 in the second channel is used to obtain the incident pulse amplitude. The two regimes are realized by switch 3 . After the generator 1 charged line discharges through the mercury-wetted relay or spark gap, the electric pulse attenuated by attenuator 2 reaches the DUT and through fixed thin film attenuators 6 and the delay line 7 is transmitted to the input of a $0-5 \mathrm{GHz}$ bandwidth memorized sampling oscilloscope. The electrical circuit is described by a simple lumped equivalent circuit, consisting of three resistors connected in series: the internal resistance of the generator $(50 \Omega)$, the sample resistance, and the oscilloscope input resistance $(50 \Omega)$. Therefore the current through the sample $I$ is equal to $U_{\text {osc }} / 50 \mathrm{~A}$, where $U_{\text {osc }}$ is the registered voltage of the transmitted pulse amplitude, and the voltage drop $U$ through the sample is equal to $2\left(U_{0}-U_{\text {osc }}\right) \mathrm{V}$, where $U_{0}$ is the incident pulse amplitude. The measurements can be performed when the DUT resistance is much higher than $50 \Omega$ wave resistance of the transmission lines.

\section{Gateless 4H-SiC channel layer for MESFETs}

The wafer where the channels were fabricated consisted of semi-insulating $4 \mathrm{H}-\mathrm{SiC}$ substrate, a $p$-type buffer layer $\left(n<5 \cdot 10^{15} \mathrm{~cm}^{-3}\right)$, and $n$-type channel layer $0.175 \mu \mathrm{m}$ thick. The samples have width $w$ of $100 \mu \mathrm{m}$ and length $L$ of $4 \mu \mathrm{m}$. They have a sheet resistance $R_{\mathrm{S}}$ of $5940 \Omega / \square$ and a low-field electron mobility of $\sim 300 \mathrm{~cm}^{2} /(\mathrm{V} \mathrm{s})$. The sample resistance then is $R=R_{\mathrm{s}} \cdot L / w$. Transmitted pulse oscillograms through the channel at high electric fields are shown in Fig. 2.

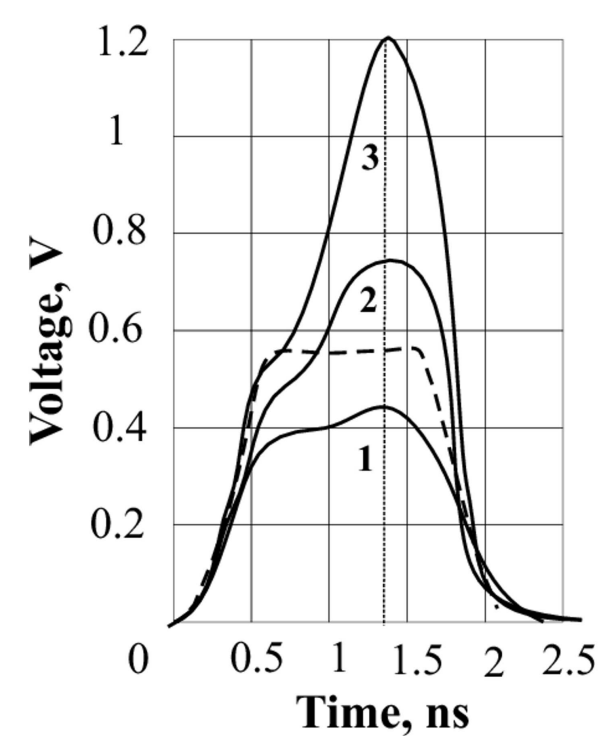

Fig. 2. Pulse oscillograms transmitted through the $4 \mathrm{H}-\mathrm{SiC}$ channel layer. 1 at $144 \mathrm{~V}, 2$ at $184 \mathrm{~V}, 3$ at $194 \mathrm{~V}$. Dashed line is the incident pulse form. Dotted line indicates time moment corresponding to steep $I-V$. Deflection factor is $0.2 \mathrm{~V} /$ div., sweep range $0.5 \mathrm{~ns} /$ div.

The results are calculated to the time moment indicated by dotted line (see Fig. 2) and show steep $I-V(194 \mathrm{~V}$ and $0.375 \mathrm{~A}$ for maximal value), while results calculated at $0.75 \mathrm{~ns}$ indicates saturated $I-V$ with current of about $0.1 \mathrm{~A}$ and voltage drop of $138 \mathrm{~V}$. The appearance of the hump in the transmitted pulse compared with unchanged incident pulse form (dashed line in Fig. 2) indicates the increase of the current. This means that there exist a family of $I-V$ characteristics at different time moments. As an example, two $I-V$ characteristics, different at high electric fields, are presented in [4]. For comparison, other authors reported on saturated $I-V$ characteristics measured in $4 \mathrm{H}-$ and $6 \mathrm{H}-\mathrm{SiC}$ up to $300 \mathrm{kV} / \mathrm{cm}$ [8]. Using the model of a homogeneous voltage and current distribution across the channel one can obtain the average electric field strength of $345 \mathrm{kV} / \mathrm{cm}$, for a current density of $5.7 \cdot 10^{5} \mathrm{~A} / \mathrm{cm}^{2}$, and for an electric field strength of $485 \mathrm{kV} / \mathrm{cm}$ the current density is $2.14 \cdot 10^{6} \mathrm{~A} / \mathrm{cm}^{2}$ in respective cases of saturated and steep $I-V$ characteristics. Both the electric field and current density are too high and the model of homogeneous voltage and current distribution across 


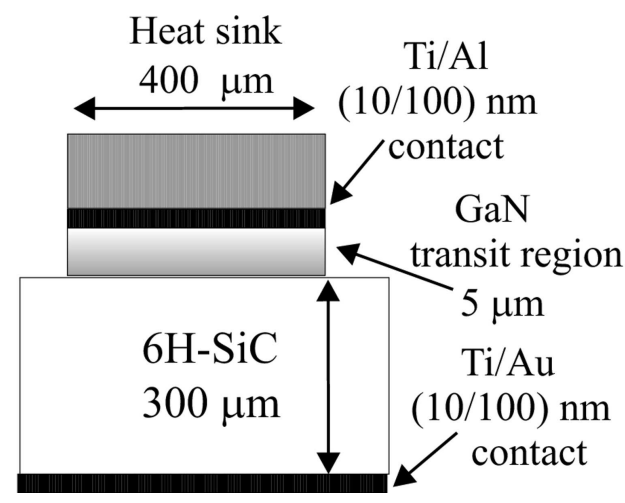

Fig. 3. Schematic diagram of the vertical GaN Gunn diode.

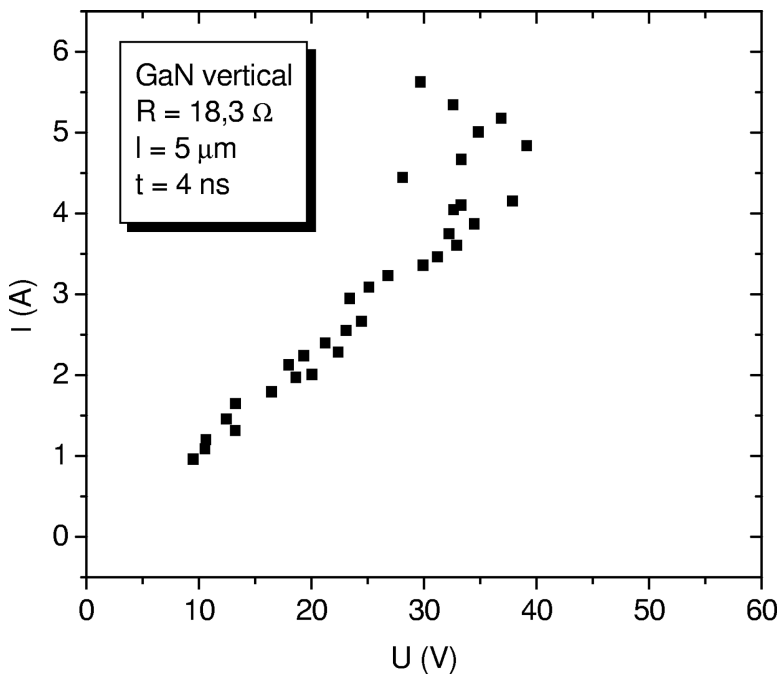

Fig. 4. $I-V$ characteristic of the vertical GaN diode. Incident pulse duration is $4 \mathrm{~ns}$.

the channel hardly describes the real situation, therefore other models must be used to clarify the current growth [4].

\section{Vertical GaN Gunn diode}

A schematic diagram of the Gunn diode is shown in Fig. 3. The GaN multilayer was grown on $6 \mathrm{H}-\mathrm{SiC}$ substrate using metal oxide chemical vapour deposition technology. It consists of (starting from $\mathrm{Ti} / \mathrm{Al}$ contact) $\mathrm{GaN} n^{+}$-doped with $\mathrm{Si}\left(2.6 \cdot 10^{18} \mathrm{~cm}^{-3}\right), \mathrm{GaN}$ notch $n^{-}$-doped with $\mathrm{Si}\left(2 \cdot 10^{15} \mathrm{~cm}^{-3}\right)$, GaN transit region $n$-doped with $\mathrm{Si}\left(1 \cdot 10^{17} \mathrm{~cm}^{-3}, L=5 \mu \mathrm{m}\right)$, and again $\mathrm{GaN} n^{+}$-doped with $\mathrm{Si}\left(2.6 \cdot 10^{18} \mathrm{~cm}^{-3}\right)$. Some increased contact resistance was observed during measurements and the total Gunn diode resistance was measured to be $18 \Omega$. The $I-V$ characteristic of the Gunn diode obtained with $4 \mathrm{~ns}$ time duration pulses is shown in Fig. 4. It is known that $N$-type negative differential resistance appears in $n$-doped $\mathrm{GaN}$ at electric field strength of $\sim 150 \mathrm{kV} / \mathrm{cm}$. However, as it is seen from Fig. 4, some undesirable features are observed at fields above $\sim 50 \mathrm{kV} / \mathrm{cm}(25 \mathrm{~V})$ and above $\sim 70 \mathrm{kV} / \mathrm{cm}$ $(35 \mathrm{~V}) . S$-type negative differential resistance is caused mainly due to current filaments. The situation becomes uncontrollable, leading to the soft Gunn diode damage. The ratio of structure diameter to multilayer thickness which is equal to 76 - is very large. The similar experiments are described in [5], but values of the ratio lie between 4 and 8 . Early breakdown of vertical GaN diode structure was observed too and was explained by small spacing $(2.2 \mu \mathrm{m})$ of transit region and, additionally, by imperfect contact adhesion.

\section{Discussion of results}

Pulse shortening up to durations of order of ns reduces Joule heating of the $4 \mathrm{H}-\mathrm{SiC}$ channel layer. Considering pulse duration $t=1 \mathrm{~ns}$ as a short dc pulse one can analyse the channel heating conditions at high electric fields. Using an adiabatic approximation and a homogeneous current distribution, when pulse power $P$ dissipated in the channel, then Joule heat $Q=P t=$ $C \rho V \Delta T$, we estimate that the channel heating just before the damage ( $E=345 \mathrm{kV} / \mathrm{cm}, I=0.1 \mathrm{~A}$ ) results in an increase of the temperature $\Delta T$ of about $45 \mathrm{~K}$ ( $V$ is the channel volume, $4 \mathrm{H}-\mathrm{SiC}$ parameters: density $\rho=$ $3210 \mathrm{~kg} / \mathrm{m}^{3}$, heat capacitance $C=1350 \mathrm{~J} /(\mathrm{kg} \mathrm{K})$ ). Taking into account thermal diffusion in the substrate at depth $l, l^{2}=D t$, with $D$ being the thermal diffusivity $D=\lambda /(\rho C)$, results in effective thickness increase of $l=0.276 \mu \mathrm{m}$ and one can obtain the smaller channel temperature increase $-19 \mathrm{~K}$, where $\lambda=330 \mathrm{~W} /(\mathrm{kg} \mathrm{K})$ has been used. $4 \mathrm{H}-\mathrm{SiC}$ semiconductor thermal conductivity values $\lambda$ lie in the range of 330-500 W/(m K). This temperature increase cannot induce damage effects in the channel.

Analysis of microscope images of irreversibly damaged GaN diodes [5], thin film attenuators, and the II-type high-temperature superconductor microstrips during the transition from superconducting to normal state [9] indicate a local character of the breakdowns induced by power nanosecond pulses. These breakdowns begin mainly at point areas of contact/thin film interface, places of high electric field concentration, defects in the channel, etc. Initial existence of such point areas leads to inhomogeneous fields and current distribution. We could also consider the known model with inhomogeneous current distribution through the cross-section when the ns pulse is considered as a short ac pulse. In this model the effective frequency of the pulse is equal to $1 / t$ and, therefore, the skin effect must be taken into 
account during heating effects estimations. However, in our case the sample dimensions are small and skin effect is not observable.

We assume that the real danger comes from the fast rising pulse front, the spectrum of which contains a high frequency part. The short pulses must have a fast pulse rise time. Alternating magnetic and electric fields intensify the electric field and current non-uniformity. The local electric field and current concentration lead to a local heating at the submicron size areas during the rise time $\tau_{\text {fr. }}$. During $\tau_{\text {fr }}(0.5 \mathrm{~ns}, \lambda$ is equal to $500 \mathrm{~W} /(\mathrm{kg} \mathrm{K})$ for $n$-doped $4 \mathrm{H}-\mathrm{SiC}$ ) heat from a point defect at the contact diffuses into semi-sphere of radius $0.24 \mu \mathrm{m}$, which means that the channel is locally heated up through the whole thickness of $0.175 \mu \mathrm{m}$. There will be heated spots of the same radius at the defects in the channel. After the front rise time the pulse that creates high electric field will continue to heat up these heated spots with further broadening of their diameters. Existence of such points in the channel induces an inhomogeneous current distribution and also possible thermally activated impact ionization or Poole-Frenkel electron emission, which causes damage of the device.

In the case of the Gunn diode (capacitor-like geometry) the electric field concentrates at spikes, which causes an inhomogeneous current distribution and, therefore, dissipated power. Using the thermal diffusion length formula $l^{2}=D \tau_{\text {fr }}$, in $\mathrm{GaN}$, one can obtain that heated spot radius is equal to $l=0.163 \mu \mathrm{m}$ during the pulse rise time for the following $\mathrm{GaN}$ parameters: density $\rho=6090 \mathrm{~kg} / \mathrm{m}^{3}$, heat capacitance $C=400 \mathrm{~J} /(\mathrm{kg} \mathrm{K})$, and thermal conductivity $\lambda=$ $130 \mathrm{~W} /(\mathrm{m} \mathrm{K})$. In this case there is a high probability of formation of a heated spot pair between the upper contact and 6H-SiC plane (see Fig. 3). During the subsequent heating up by the flat part of the high voltage pulse, paths with increased current density will be formed through the diode $5 \mu \mathrm{m}$ transit layer between the pairs. Most probably, this causes earlier damage of the vertical Gunn diode structure with high ratio of the diameter to multilayer thickness. The appearance of the effect is independent of whether a single pulse or a series of pulses has been used during the $I-V$ measurements.

\section{Conclusions}

A modified method was used to provide the $I-V$ measurements in nanosecond time scale. Model of homogeneous current distribution trough a cross-section of the device does not allow one to explain the degradation of the devices at high electric fields because of small temperature increase. Model on the nonhomogeneous current distribution due to skin effect cannot be applied to explain the degradation effects because of small dimensions of the devices. Thus, we conclude that the fast rising pulses of nanosecond duration creating the fields higher than $50 \mathrm{kV} / \mathrm{cm}$ do not cause the temperature rise of the whole device volume (Joule heating), but become dangerous due to development of overheating, which begins by heating of submicron inhomogeneities during the subnanosecond pulse rise time.

\section{References}

[1] W. Jantsch and H. Heinrich, A method for subnanosecond pulse measurements of $I-V$ characteristics, Rev. Sci. Instrum. 41, 228-230 (1970).

[2] A. Dargys, Drift Velocity Measurements in Solids (Mokslas, Vilnius, 1987) [in Russian].

[3] L. Ardaravičius, O. Kiprijanovič, and J. Liberis, Relaxation of conductivity in $\mathrm{AlGaN} / \mathrm{AlN} / \mathrm{GaN}$ twodimensional electron gas at high electric fields, Lithuanian J. Phys. 47, 485-489 (2007).

[4] L. Ardaravičius, A. Matulionis, O. Kiprijanovič, J. Liberis, H.-Y. Cha, L. Eastman, and M. Spencer, Hot-electron transport in 4H-SiC, Appl. Phys. Lett. 86, 022107 (2005).

[5] K. Mutamba, O. Yilmazoglu, C. Sydlo, M. Mir, S. Hubbard, G. Zhao, I. Daumiller, and D. Pavlidis, Technology aspects of GaN-based diodes for high field operation, Superlatt. Microstruct. 40, 363-368 (2006).

[6] A. Agarwal and S. Haney, Some critical materials and processing issues on $\mathrm{SiC}$ power devices, J. Electron. Mater. 37, 646-654 (2008).

[7] O. Yilmazoglu, K. Mutamba, D. Pavlidis, and T. Karaduman, First observation of bias oscillations in GaN Gunn diodes on GaN substrate, IEEE Trans. Electron Devices 55, 1563-1566 (2008).

[8] I. Khan and J.A. Cooper, Measurement of high-field electron transport in silicon carbide, IEEE Trans. Electron Devices 47, 269-276 (2000).

[9] S. Balevičius, V. Balčiūnas, A. Čenys, B. Vengalis, F. Anisimovas, R. Butkute, V. Lisauskas, and V. Jasutis, Damage to high- $T_{\mathrm{c}}$ superconducting microstrips induced by ultrafast S-N switching, Lithuanian J. Phys. 35, 622625 (1995). 


\title{
GREITAVEIKIŲ SiC IR GaN GALIOS PRIETAISU VOLTAMPERINIU巳 CHARAKTERISTIKŲ MATAVIMAS NANOSEKUNDINIAIS IMPULSAIS
}

\author{
L. Ardaravičius ${ }^{a}$, M.J. Kelly ${ }^{b}$, M. Kappers ${ }^{\text {c }}$, O. Kiprijanovič ${ }^{a}$, S. Whelan ${ }^{b}$ \\ ${ }^{a}$ Puslaidininkiu fizikos institutas, Vilnius, Lietuva \\ ${ }^{\mathrm{b}}$ Kembridžo universiteto Šiuolaikinès fotonikos ir elektronikos centras, Kembridžas, Jungtinè Karalystė \\ ${ }^{\mathrm{c}}$ Kembridžo universiteto Medžiagotyros ir metalurgijos departamentas, Kembridžas, Jungtinè Karalystė
}

\section{Santrauka}

Plačiajuosčių puslaidininkių, tokių kaip $\mathrm{GaN}$ ir $\mathrm{SiC}$, pramušimo laukų vertès yra didelès. Jei matuojant šių plačiajuosčių puslaidininkinių prietaisų voltamperines charakteristikas naudojami galingi impulsai, prietaisai gali būti suardyti dèl Džaulio šilumos išsiskyrimo. Mūsų eksperimentuose $4 \mathrm{H}-\mathrm{SiC}$ bandinys ir GaN Gano diodas buvo patalpinti nuosekliai perdavimo linijoje, o etaloninis rezisto- rius naudotas krintančio impulso amplitudei nustatyti. Šis pagerintas būdas leidžia atlikti matavimus nanosekundžių trukmès impulsais ir tuo būdu išvengti Džaulio kaitimo. Šie prietaisai, veikiantys stipriuose elektriniuose laukuose (virš $50 \mathrm{kV} / \mathrm{cm}$ ), gali būti suardyti dèl trumpų elektrinių impulsų sukelto lokalaus perkaitimo, kuris prasideda submikroninių matmenų nehomogeniškumuose impulso fronto veikos metu. 